\title{
Control of vertical transmission of Renibacterium salmoninarum by injection of antibiotics into maturing female coho salmon Oncorhynchus kisutch
}

\author{
L. L. Brown ${ }^{1}$, L. J. Albright ${ }^{1}$, T. P. T. Evelyn ${ }^{2, *}$ \\ ${ }^{1}$ Institute of Aquaculture Research, Department of Biological Sciences, Simon Fraser University, Burnaby, British Columbia, \\ Canada V5A 1 S6 \\ ${ }^{2}$ Department of Fisheries and Oceans, Biological Sciences Branch, Pacific Biological Station, Nanaimo, British Columbia, \\ Canada V9R 5K6
}

\begin{abstract}
A study was conducted to evaluate the levels of drugs attained in eggs and alevins as a result of injecting antibiotics into pre-spawning female salmon Oncorhynchus kisutch and to evaluate if this was an effective means of controlling vertical transmission of Renibacterium salmoninarum (Rs), the causative agent of bacterial kidney disease. Five antibıtics (erythromycin phosphate, penicillin G, oxytetracycline, cephradine, and rifampicin) were injected into the 'dorsal sinus' of maturing female coho salmon, one antibiotic per fish, 2 to $3 \mathrm{wk}$ before spawning. Eggs from these fish were then infected internally with $R s$ using a microinjection technique. The prevalence of the resulting infections was determined for the eggs at the eyed stage and for alevins at hatch. Concentrations of each antibiotic were measured in the egg yolk at spawning and in the alevins at hatch. All 5 antibiotics were detected in eggs taken at spawning, but only erythromycin and rifampicin were present in measurable amounts within the alevins at hatch. The 5 antibiotics all proved to be effective in significantly reducing the prevalence of $R s$ infections by the hatch stage. The broodstock injection technique therefore appears to be a promising means of reducing the vertical transmission of $R s$.
\end{abstract}

\section{INTRODUCTION}

The causative agent of bacterial kidney disease (BKD), Renibacterium salmoninarum $(R s)$, can be transmitted vertically (Bullock et al. 1978), the pathogen being transmitted within the egg (Evelyn et al. $1984 \mathrm{a}$, b). Eggs have been shown to acquire infections following ovulation when surrounded by heavily contaminated coelomic fluid (Evelyn et al. 1986b) and there is also evidence that they can become infected during oogenesis (Lee \& Gordon 1987, Lee \& Evelyn 1989).

Within the salmonid egg, Rs is not affected by surface-disinfection with povidone-iodine solutions; thus, this procedure is ineffective in controlling vertical transmission of Rs (Evelyn et al. 1984a, b, 1986c). Several antibiotics have been shown to be active against $R s$ in vitro (Wolf \& Dunbar 1959, Austin 1985), and one of

\footnotetext{
- Author to whom correspondence should be addressed

them, erythromycin, has been recommended as a chemotherapeutic agent for the treatment of BKD (Austin 1985). However, water-hardening salmonid eggs in an erythromycin solution did not reduce the prevalence of intra-ovum $R s$ and did not result in detectable yolk concentrations of the antibiotic (Evelyn et al. 1986b).

Injection of erythromycin into the 'dorsal sinus' of maturing female salmon is a recommended procedure for reducing pre-spawning mortalities due to BKD Groman \& Klontz 1983, Evelyn 1988, Elliott et al. 1989). It has been shown that this procedure results in the deposition of erythromycin in the egg, and that the drug persists within the yolk material of the eggs and sac fry at levels greater than the reported in vitro minimum inhibitory concentration (MIC) (Bullock \& Leek 1986, Evelyn et al. 1986a, Armstrong et al. 1989). The antibiotic within the egg should therefore be effective in reducing or eliminating intra-ovum Rs infections, and observations on the progeny of adult females 
injected with erythromycin before spawning support this hypothesis (Groman \& Klontz 1983, Armstrong et al. 1989).

This study was conducted to ascertain whether vertical transmission of $R s$ could be controlled by injecting female coho salmon prior to spawning with selected antibiotics and to determine the level and persistence of the antibiotics in the resulting eggs and alevins. Five antibiotics were selected for the study (erythromycin phosphate, penicillin G, oxytetracycline, cephradine, and rifampicin) because of their reported in vitro activity against $R s$ (Austin 1985).

\section{MATERIALS AND METHODS}

Eggs and milt. Eggs and milt used in this study were obtained frum adult coho saminon that had returned to the Capilano River, North Vancouver, B. C., Canada, to spawn. Thirty-six fish were injected with antibiotics or saline as described below and were then held at the Capilano Hatchery (Department of Fisheries and Oceans) until mature. Surviving fish, which appeared normal by internal and external examination, were spawned and their eggs and milt were collected and transported to the laboratory in separate clean, sterile, iced, plastic containers, charged with oxygen to ensure viability. The eggs and milt were stored at $4{ }^{\circ} \mathrm{C}$ overnight. Culture (Daly \& Stevenson 1985) and indirect fluorescent antibody tests (IFAT) (Bullock \& Stuckey 1975) failed to detect any $R_{s}$ cells in samples of coelomic fluid and milt obtained from these fish.

Bacteria. Isolate \#384 of $R$ s (Evelyn et al. $1984 \mathrm{a}, \mathrm{b}$ ) was used to artificially infect eggs. The isolate was grown for $21 \mathrm{~d}$ at $15^{\circ} \mathrm{C}$ on charcoal agar (SKDM-C) (Daly \& Stevenson 1985), which was made selective by the addition of antibiotics as specified by Austin et al. (1983). Growth on the plates was suspended in sterile peptone-saline $(\mathrm{P}-\mathrm{S} ; 0.1 \% \mathrm{w} / \mathrm{v}-0.85 \% \mathrm{w} / \mathrm{v}$, respectively). The suspension was adjusted to $2.0 \mathrm{OD}$ at $420 \mathrm{~nm}$, equivalent to approximately $1 \times 10^{8} \mathrm{cells} \mathrm{ml}^{-1}$.
The suspension was then diluted with sterile P-S to give a final concentration of approximately $1 \times 10$ cells $\mathrm{ml}^{-1}$, and was held on ice until used for infecting the eggs (described below).

Antibiotics. Five antibiotics, known to be active against $R s$ in vitro (Austin 1985) were chosen for this study: erythromycin phosphate, penicillin G, oxytetracycline, cephradine, and rifampicin. They were obtained from Sigma Chemical Co. Ltd., (St. Louis, MI, USA). Solutions of antibiotics (one concentration per drug, as shown in Table 1) were prepared in sterile saline $(0.85 \% \mathrm{w} / \mathrm{v} \mathrm{NaCl})$ and were injected to provide doses suggested by earlier in vivo (Evelyn et al. 1986a, Armstrong et al. 1989) and in vitro (Austin 1985) studies (Table 1).

Experimental procedure. Thirty-six maturing female coho salmon were held at the hatchery and were divided randomly into 6 groups of 6 fish cach. Fish were anaesthetized with $0.025 \%$ (w/v) 2-phenoxyethanol (Syndel Laboratories, Vancouver, B.C.), weighed, and injected with one antibiotic each. Injections were administered in the 'dorsal sinus'. Five antibiotics were injected, providing a total of 5 test groups. The sixth group was the control; each fish in this group received an injection of sterile saline. The fish groups were marked by opercular punches and then held in a common pen in fresh water at an average temperature of $7^{\circ} \mathrm{C}$. The fish that did not succumb to fungal infections were spawned from 14 to $26 \mathrm{~d}$ following antibiotic injection. Milt, pooled from 2 to 3 untreated male coho salmon, was used to fertilize the eggs as outlined below.

Fifty eggs from each fish were artificially infected with Rs using a microinjection procedure (Brown et al. 1990). Approximately $10 \mathrm{Rs}$ cells were microinjected into each of 50 non-water-hardened, unfertilized eggs obtained from a given female. After injection, each group of eggs was fertilized in a clean dry beaker on ice, using approximately $0.5 \mathrm{ml}$ milt. After $1 \mathrm{~min}$, the eggs were rinsed with chilled $\left(10^{\circ} \mathrm{C}\right)$, sterile, distilled water, water-hardened for $2 \mathrm{~h}$ in 10 volumes of chilled,

Table 1. Dose of antibiotics injected into the dorsal sinus of female coho salmon Oncorhynchus kisutch before spawning and the number of fish that survived to spawn. All antibiotics injected were dissolved in $0.85 \%(\mathrm{w} / \mathrm{v}) \mathrm{NaCl}: \mathrm{E}=20.0 \mathrm{mg} \mathrm{ml} \mathrm{m}^{-1}, \mathrm{P}=166.7$ $\mathrm{mg} \mathrm{ml} \mathrm{m}^{-1}, \mathrm{O}=20.0 \mathrm{mg} \mathrm{ml}^{-1}, \mathrm{C}=41.7 \mathrm{mg} \mathrm{ml}^{-1}, \mathrm{R}=13.9 \mathrm{mg} \mathrm{m}^{-1}$. Injection volumes were sufficient to provide doses indicated. Control fish were injected with $0.85 \%(\mathrm{w} / \mathrm{v}) \mathrm{NaCl}\left(1.0 \mathrm{ml} \mathrm{kg}^{-1} \mathrm{fish}\right)$

\begin{tabular}{|lccc|}
\hline Treatment & $\begin{array}{c}\text { Dose of antibiotic injected } \\
\text { (mg drug kg }{ }^{-1} \text { fish) }\end{array}$ & No. fish injected & No.fish spawned \\
\hline Erythromycin phosphate (E) & 20 & 6 & 4 \\
Penicillin G (P) & 50 & 6 & 4 \\
Oxytetracycline (O) & 10 & 6 & 3 \\
Cephradine (C) & 25 & 6 & 2 \\
Rifampicin (R) & 5 & 6 & 3 \\
Control & 0 & 6 & 3 \\
\hline
\end{tabular}


sterile, distilled water, and then surface-disinfected for $10 \mathrm{~min}$ in $400 \mathrm{ppm} \mathrm{I}_{2}$ in the form of Ovadine (Syndel Laboratories, Vancouver, B.C.). Finally, eggs were rinsed 3 times in 10 volumes of chilled, sterile, distilled water to remove the disinfectant. Each egg was then transferred to a screw-capped, polystyrene culture tube containing $5 \mathrm{ml}$ of chilled, sterile, double-distilled water and then incubated in the dark at $10^{\circ} \mathrm{C}$.

Eyed eggs and alevins from each fish were assayed for viable Rs cells. Ten eggs at the eyed stage and 5 to 10 alevins at hatch were taken from each 'fish-lot' (one 'fish-lot' indicates the 50 artificially infected eggs originating from a single fish). Eggs and alevins were removed from culture tubes, blotted dry on sterile filter paper, and then transferred to clean, dry, sterile culture tubes (one egg per tube). The eyed eggs were pierced with a sterile needle, their contents expressed, and the chorion removed and discarded. Alevins were homogenized whole using a Polytron homogenizer (Brinkmann Instruments). In order to enhance the numbers of any Rs cells present to detectable levels (Evelyn et al. $1984 \mathrm{a}$, b), the egg contents and homogenized alevins were individually incubated in $5 \mathrm{ml}$ of SKDM-2 broth (Austin et al. 1983) at $15^{\circ} \mathrm{C}$ for 5 to $6 \mathrm{wk}$. (Use of 5 $\mathrm{ml}$ of SKDM-2 ensured that any residual antibiotic in the eggs or alevins would be diluted to below the lethal level for Rs.) Following incubation, Rs cells were pelleted by centrifugation $\left(3000 \times g\right.$ for $30 \mathrm{~min}$ at $\left.4{ }^{\circ} \mathrm{C}\right)$, resuspended in $1 \mathrm{ml}$ of decanted supernatant, and then $25 \mu$ l of the suspension was dropped peripherally onto 3 SKDM-C plates. Growth in these samples was enhanced using the 'nurse-culture' technique (Evelyn et al. 1989). Plates were incubated at $15^{\circ} \mathrm{C}$ for 2 to $3 \mathrm{wk}$ and resulting growth was examined by IFAT to determine whether it was Rs. Results are given as the percentage of eyed eggs or alevins from treated or control fish that yielded viable Rs cells (Fig. 1, Table 2).

Assay of antibiotic concentrations. To determine the level of each antibiotic deposited in eggs and its persistence in the eggs to the hatch stage, assays were carried out on yolk samples from 10 freshly spawned eggs per spawner and on homogenized tissues of 3 to 5 freshly hatched alevins per spawner. Similar samples from saline-injected (control) fish were also assayed. Yolk samples were collected by blotting the eggs dry on sterile filter paper, expressing the egg contents into a dry, sterile tube, and removing and discarding the chorion. The alevins were blotted dry and homogenized whole. Drug concentrations in the yolk and homogenized alevin samples were assayed using a modified cylinder-plate method with sensitive bacterial species (Difco 1968, Evelyn et al. 1986b). Samples were assayed for erythromycin phosphate concentrations using a sensitive strain of Micrococcus luteus and for the other 4 antibiotics using a sensitive strain of
Staphylococcus aureus. Results are expressed as the average of the antibiotic concentrations within the eggs or alevins assayed (Table 3 ).

Statistical analysis. The mean intra-ovum $R$ s infection rates in eggs from treated and control fish were compared using a Students t-test (KWIKSTAT 1989) to determine whether or not they were significantly different. In order to perform the Students t-test the data were transformed by taking the arcsin of the square root of the proportion of samples containing viable $R s$ (Snedecor 1956, p. 316-317). Similarly, Rs infection rates in alevins from treated and control spawners were also compared. The probability that the differences in the infection rates in treated and control samples were due to chance is expressed as $p$ (Table 2).

\section{RESULTS AND DISCUSSION}

The results indicate that injection of any one of the 5 tested antibiotics into maturing female coho salmon was an effective means of reducing the prevalence of infection due to $R s$ in their progeny. Fig. 1 shows the prevalence of $R s$ infection in eyed eggs and alevins taken from each spawner, and Table 2 summarizes the mean prevalence of infection in eyed eggs and alevins from each experimental group of spawners. Cephradine and rifampicin had a lethal effect on $R s$ by the time the eyed stage was reached. However, at this stage there was no significant reduction in the prevalence of infection within the groups of eggs taken from fish treated with erythromycin phosphate, penicillin $G$, or oxytetracycline. Significantly, however, in all of the antibiotic-treated groups there was a decided reduction in the proportion of alevins found to contain viable $R s$ cells by the hatch stage.

The delayed anti-Rs effect of erythromycin phosphate, penicillin $G$, and oxytetracycline relative to cephradine and rifampicin may be an intrinsic property of the drugs because similar results were obtained in a parallel in vitro study (data not shown).

Prevalences of $R$ s infection varied between samples of eggs or alevins taken from different fish within a treatment group. Fig. 1 illustrates this 'fish-to-fish' variation which may have been partly due to a variable leakage of antibiotic from the injection site in the fish.

No antibiotic was effective in eliminating the pathogen from all of the eggs or alevins, and further experiments are obviously warranted to determine whether the effectiveness of the broodstock antibiotic injection procedure can be improved. Future tests should investigate the efficacy of higher doses and multiple injections of the antibiotics.

Table 3 summarizes the results of antibiotic assays carried out on eggs at spawning and alevins at hatch. 

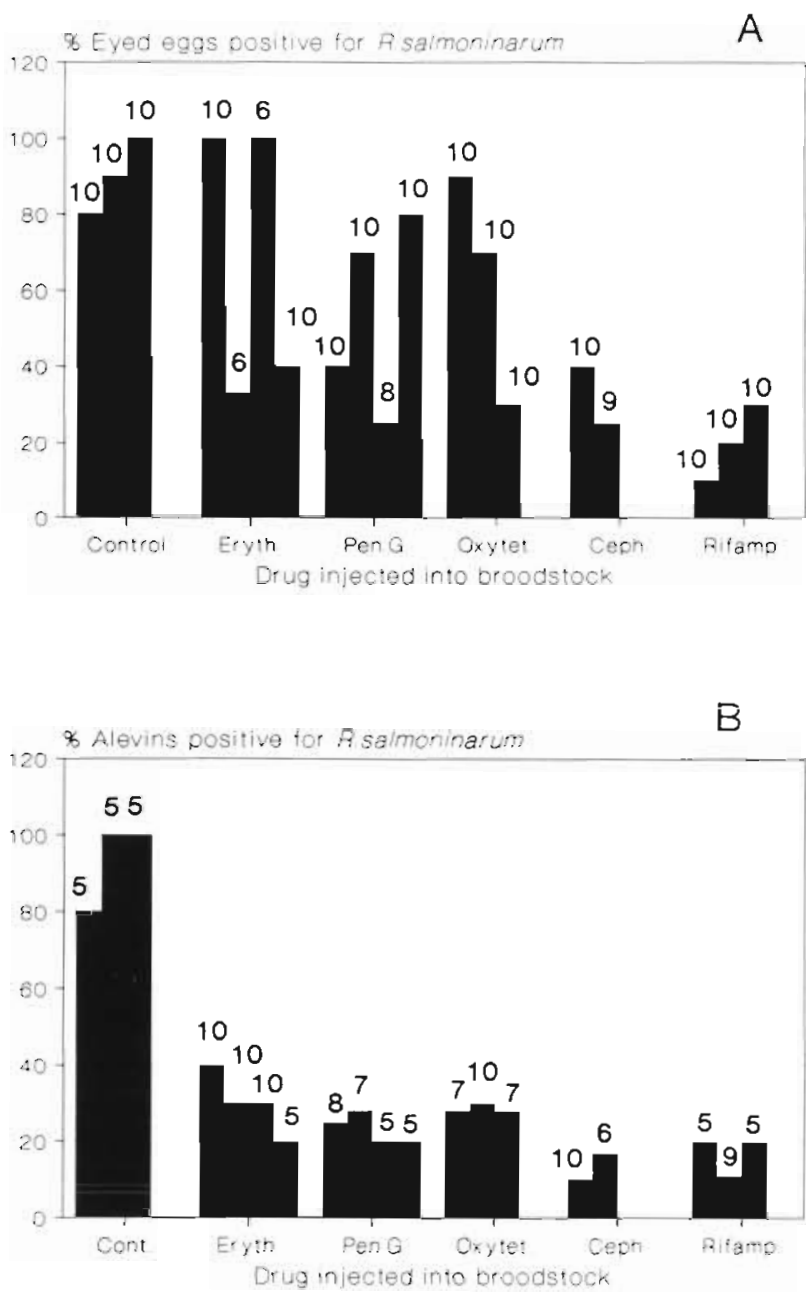

Fig. 1 Prevalence of infection due to Renibacterium salmoninarum (Rs) in Oncorhynchus kisutch eggs. Each bar represents portion of eyed eggs (A) or alevins (B) per spawner that contained viable $R s$ cells; Nos. above bars indicate no. tested. Abbreviations are: (Eryth.) Erythromycin phosphate; (Pen.G) Penicillin G; (Oxytet.) Oxytetracycline; (Ceph.) Cephradine; (Rifamp.) Rifampicin
Erythromycin was deposited in the egg before spawning, and persisted within the yolk material throughout egg incubation and up to the alevin stage, confirming the findings of others (Bullock \& Leek 1986, Evelyn et al. 1986a, Armstrong et al. 1989). Injection of prespawning female salmon with the other antibiotics also resulted in their deposition in yolk material.

Intra-ovum concentrations of erythromycin phosphate and rifampicin dropped during incubation; however, levels of these 2 antibiotics within alevins at hatch were still at or higher than their reported in vitro MIC (Austin 1985, Evelyn et al. 1986b). No antimicrobial activity was evident in alevins derived from fish treated with penicillin $G$, oxytetracycline, or cephradine. However, these drugs obviously persisted in eggs at concentrations sufficient to significantly reduce the prevalence of $R s$ in alevins hatching from these eggs.

Pre-spawning injection of each of the 5 tested antibiotics into female brood salmon resulted in the deposition of each of the drugs in the yolk material of the eggs. Further, the drugs persisted in the eggs at concentrations sufficient to significantly reduce the proportion of the eggs that contained the viable pathogen. We conclude, therefore, that the pre-spawning injection procedure is a promising method for controlling the vertical transmission of Rs.

Acknowledgements. The cooperation and support of E. Stone and his staff at Capilano Hatchery are gratefully acknowledged. We also thank J. Ketcheson and L. Prosperi-Porta for their valuable technical assistance. This project was supported, in part, by a Natural Sciences and Engineering Research Council operating grant to L.J.A.

\section{LITERATURE CITED}

Armstrong, R. D., Evelyn, T P. T., Martin, S. W., Dorward, W., Ferguson, H. W. (1989). Erythromycin levels within eggs and alevins derived from spawning broodstock chinook

Table 2. Mean \pm SD prevalences of Renibacterium salmoninarum (Rs) infections in eyed eggs and freshly hatched alevins derived from variously treated Oncorhynchus kisutch spawners. n = no. fish that survived to spawn. within each treatment group; p: level of significance (confidence interval). Comparisons of the mean prevalence of infection in each experimental group with the mean of the control group was done using a Students t-test (see text); $p>0.05$ indicates no significant difference. Control fish were injected with saline $(0.85 \%$ w/v) only

Treatment Prevalence of viable $R s$ in

Eyed eggs

Alevins

n $\%$ positive for Rs

$\mathrm{p}$

$\%$ positive for Rs $\mathrm{p}$

Control

Erythromycin

Penicillin $G$

Oxytetracycline

Cephradine

Rifampicin
$90 \pm 8.2$

$68 \pm 36.8$

$54 \pm 25.6$

$63 \pm 11.5$

$32 \pm 10.6$

$20 \pm 10.0$
0.585

0.057

0.236

0.034

0.006
$93 \pm 11.5$
$30 \pm 8.2$
$23 \pm 3.9$
$29 \pm 1.2$
$14 \pm 4.9$
$17 \pm 5.2$

0.002

0.001

0.006

0.015

0.004 
Table 3. Average \pm SE antibiotic concentrations (determined by a modified cylinder plate method using sensitive strains of Micrococcus luteus or Staphylococcus aureus) detected in coho salmon Oncorhynchus kisutch eggs taken at spawning and in whole alevins at hatch. nd: not present in detectable amounts

\begin{tabular}{|lcccc|}
\hline Antibiotic & \multicolumn{2}{c|}{ Antibiotic concentration (ug ml ${ }^{-1}$ ) } \\
& $\mathrm{n}$ & Eggs & $\mathrm{n}$ & Alevins \\
\hline Erythromycin phosphate & 40 & $1.10 \pm 0.57$ & 18 & $0.30 \pm 0.33$ \\
Penicillin G & 40 & $0.25 \pm 0.01$ & 16 & $\mathrm{nd}$ \\
Oxytetracycline & 30 & $1.20 \pm 0.00$ & 10 & $\mathrm{nd}$ \\
Cephradine & 20 & $0.50 \pm 0.00$ & 9 & $\mathrm{nd}$ \\
Rifampicin & 30 & $2.67 \pm 0.66$ & 13 & $0.25 \pm 0.00$ \\
\hline
\end{tabular}

salmon Oncorhynchus tshawytscha injected with the drug. Dis. aquat. Org. 6: $33-36$

Austin, B., Embley, T M., Goodfellow, M. (1983). Selective isolation of Renibacterium salmoninarum. FEMS Microbiol. Lett. 17: 111-114

Austin, B. (1985). Evaluation of antimicrobial compounds for the control of bacterial kidney disease in rainbow trout, Salmo gairdneri Richardson. J. Fish Dis. 8: 209-220

Brown, L. L., Ricks, R., Evelyn, T P. T., Albright, L. J. (1990). Experimental intra-ovum infection of coho salmon (Oncorhynchus kisutch) eggs with Renibacterium salmoninarum using a microinjection technique. Dis. aquat. Org. 8: 7-11

Bullock, G. L., Leek, S. L. (1986). Use of erythromycin in reducing vertical transmission of bacterial kidney disease. Vet. Hum. Toxicol., Suppl. 1. 18-20

Bullock, G. L., Stuckey, H. M. (1975). Fluorescent antibody identification and detection of the Corynebacterium causing kidney disease of salmonids. J. Fish. Res. Bd Can. 32 : 2224-2227

Bullock, G. L., Stuckey, H. M., Mulcahy, D. (1978). Corynebacterial kidney disease: egg transmission following iodophore disinfection. Fish Health News 7: 51-52

Daly, J. G., Stevenson, R. M. W. (1985). Charcoal agar, a new growth medium for the fish disease bacterium, Renibacterium salmoninarum. Appl. environ. Microbiol. 50: $868-871$

Difco (1968) Supplementary literature. Difco Laboratories, Detroit, Michigan

Elliott, D. G., Pascho, R. J., Bullock, G. L. (1989). Developments in the control of bacterial kidney disease of salmonid fishes. Dis. aquat. Org. 6: 201-215

Evelyn, T P. T. (1988). Bacterial kidney disease in British Columbia: comments on its epizootiology and on methods for its control on fish farms. In: AquaNor' 87 International Conference, Norwegian Fish Farms Association and Sales Organization, 7001 Trondheim, Norway, p. 51-57

Evelyn, T. P. T., Bell, G. R., Prosperi-Porta, L., Ketcheson, J. E. (1989). A simple technique for accelerating the growth of the kidney disease bacterium Renibacterium salmoninarum on a commonly used culture medium (KDM2). Dis aquat. Org. 7: 231-234

Editorial responsibility: Managing Editor
Evelyn, T P. T., Ketcheson, J. E., Prosperi-Porta, L. (1984a). Further evidence for the presence of Renibacterium salmoninarum in salmonid eggs and for the failure of povidone-iodine to reduce the intra-ovum infection rate in water-hardened eggs. J. Fish Dis. 7: 173-182

Evelyn, T P. T., Ketcheson, J. E., Prosperi-Porta, L. (1986a). Use of erythromycin as a means of preventing vertical transmission of Renibacterium salmoninarum. Dis. aquat. Org. 2: 7-11

Evelyn, T. P. T., Prosperi-Porta, L., Ketcheson, J. E. (1984b). The salmonid egg as a vector of the kidney disease bacterium, Renibacterium salmoninarum. In: ACUIGRUP (ed.) Fish Diseases, 4th COPRAQ Session. EDITORA ATP, Madrid, Spain, p. 111-117

Evelyn, I P. T., Prosperi-Porta, L., Ketcheson, J. E. (1986b). Experimental intra-ovum infection of salmonid eggs with Renibacterium salmoninarum and vertical transmission of the pathogen with such eggs despite their treatment with erythromycin. Dis. aquat. Org. 1- 197-202

Evelyn, T P. T., Prosperi-Porta, L., Ketcheson, J. E. (1986c) Persistence of the kidney disease bacterium, Renibacterium salmoninarum, in coho salmon, Oncorhynchus kisutch (Walbaum), eggs treated during and after waterhardening with povidone-iodine. J. Fish Dis. 9: 461-464

Groman, D. B., Klontz, G. W. (1983). Chemotherapy and prophylaxis of bacterial kidney disease with erythromycin. J. Wld Maricult. Soc. 14: 226-235

KWIKSTAT (1989). Computer Software Package, Version 2.00. TexaSoft, Cedar Hill, Texas

Lee, E. G.-H., Evelyn, T. P. T. (1989). Effect of Renibacterium salmoninarum levels in the ovarian fluid of spawning chinook salmon on the prevalence of the pathogen in their eggs and progeny. Dis. aquat. Org. 7: 179-184

Lee, E. G.-H., Gordon, M. R. (1987). Immunofluorescence screening of Renibacterium salmoninarum in the tissues and eggs of farmed chinook salmon spawners. Aquaculture 65: 7-14

Snedecor, G. W. (1956). Statistical methods. Iowa State College Press, Ames, lowa

Wolf, K., Dunbar, C. E. (1959). Test of 34 chemotherapeutic agents for control of kidney disease in trout. Trans. Am. Fish. Soc. 88: 117-134

Manuscript first received: February 12, 1990

Revised version accepted: July 4, 1990 